
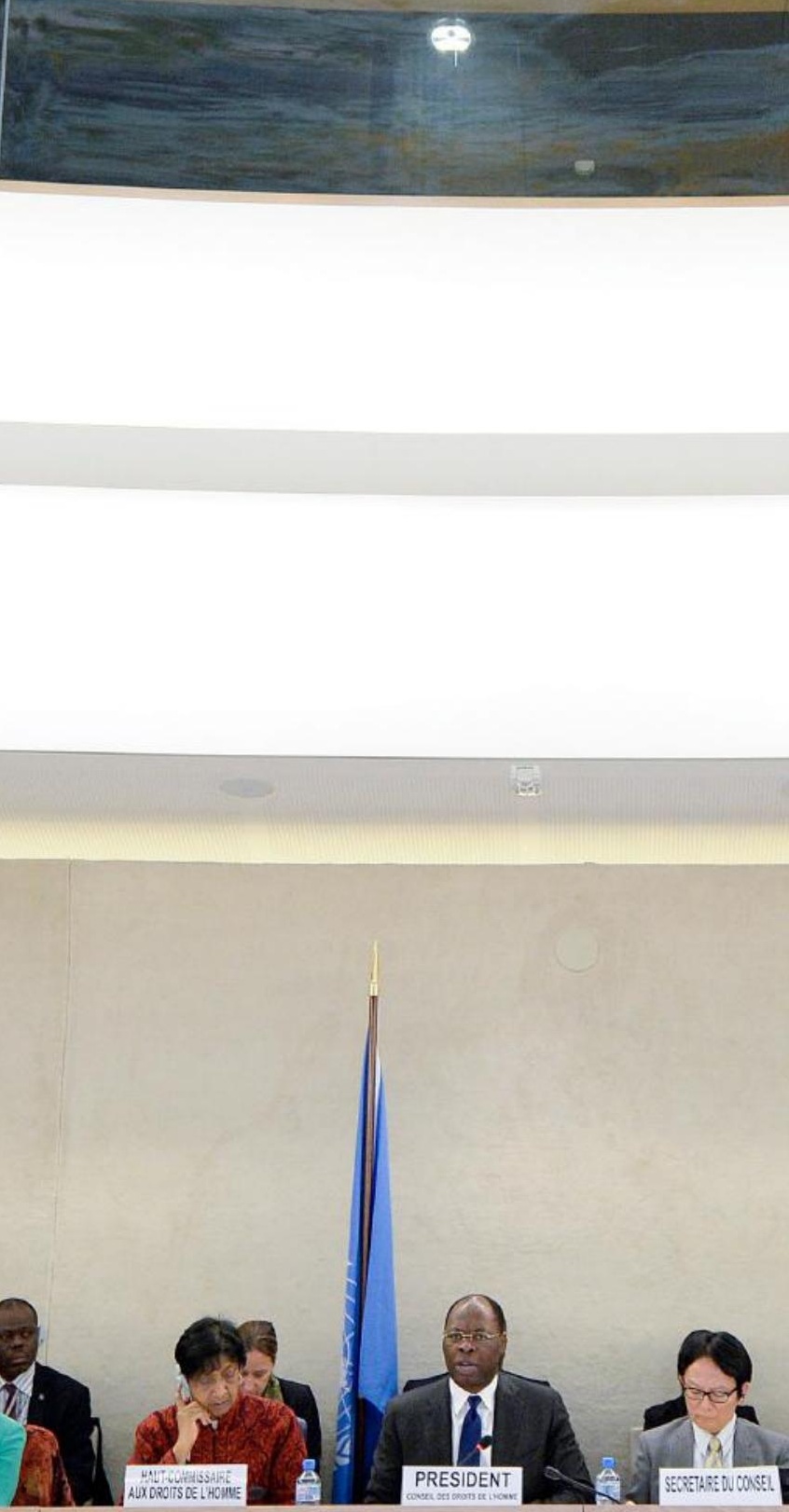


\title{
RAPE IN THE DEMOCRATIC REPUBLIC OF THE CONGO: A GENDERED APPROACH TO THE PROLIFERATION OF SEXUALIZED VIOLENCE AGAINST CHILDREN
}

\section{By Airianna Murdoch-Fyke}

\author{
JD candidate at \\ University of Ottawa
}

Content warning: this paper includes some explicit details of sexual violence.

\section{ABSTRACT}

Gendered and sexualized violence are serious issues plaguing the Democratic Republic of the Congo (DRC). Sexualized violence promotes patriarchal control over populations and leads to the debasing of women and girls in afflicted regions. Sexualized violence and rape are committed to ethnically cleanse regions, assert patriarchal dominance, and incite fear in affected areas. The utilization of rape serves as an effective tool to force girls into a submissive victimized role and taint the ethnic composition of future populations through forced pregnancies. The proliferation of rape has serious connotations for victims and for communities. Rape damages the social cohesion of regions and forces victims to become social pariahs. Sexualized violence creates long-term psychosocial impairments which limit 
the victim's ability to reintegrate into society successfully, and further damages the sense of self that girls, under the age of eighteen, are beginning to develop at the time of their attack. Furthermore, sexual and gender-based violence (SGBV) disrupts future economic capabilities of afflicted children which leads to a continuation of poverty and sexual violence. Finally, violent acts of rape and subsequent torture experienced by many children in the DRC have significant physical impacts which produce lifelong physical impediments for victims. In order to address such gendered atrocities this paper asserts a developmental framework must be applied in order to promote sustainable development within the region. This initiative must include the simultaneous implementation of the following four pillars: gender equality, education, healthcare, and responsible governance. While it will be challenging to successfully implement all four pillars during such high incidence of conflict, it is a necessary step that must be taken to permanently address the ongoing violence and the subsequent impact this conflict has on children in the Democratic Republic of the Congo.

\section{INTRODUCTION}

In this article the term sexualized violence will be characterized by the definition created by the World Health Organization WHO) which states:
sexual violence encompasses acts that range from verbal harassment to forced penetration, and an array of types of coercion, from social pressure and intimidation to physical force. Sexual violence includes but is not limited to: rape within marriage, systematic rape, sexual slavery and other forms of violence, which are particularly common in armed conflicts, and customary forms of sexual violence such as forced marriage or cohabitation. ${ }^{1}$

Furthermore, throughout this article rape will be characterized as the act of sexual intercourse that results from the desire to control, dominate, and assert power and fear within the victim and the community in which they reside. Additionally, this paper will utilize the framework of rape developed by Scott Anderson, who states, "rape can be understood to involve coercion for purposes of sexual gratification from another or causing her sexual humiliation or degradation." ${ }^{2}$ Moreover, rape will be considered as a gendered crime, since it is almost always perpetrated by men against women, with damaging effects both on individual women as well as on women as a group. ${ }^{3}$ Finally, in this article the term gender is utilized and will refer to

1 "Understanding and Addressing Violence Against Women," World Health Organization, accessed April 10, 2018, http://apps.who.int/iris/bitstream/handle/10665/77434/WHO_RHR_12.37_eng.pdf;jsessionid=21CA70885B65A6DD975646CC11F5AEAF? sequence $=1$.

2 Scott Allen Anderson, "Conceptualizing Rape as Coerced Sex," SSRN Electronic Journal, (September 2015): 6. 
the definition employed by the WHO, which states gender is a set of, "socially constructed characteristics of women and men - such as normal roles and relationships of and between groups of women and men." ${ }^{4}$

\section{CONTEXT OF GENDER AND VIOLENCE IN THE DRC}

Rape, sexualized violence, and gender discrimination are facets of every patriarchal society. Rape is utilized to portray dominance over another, sexualized violence is promoted as a tool to degrade, dehumanize, and damage women, and gendered discrimination is employed to systematically ensure women and girls are unequal, unwanted, and unprivileged due to their gender identity. Rape is a weapon employed by militias, militaries, and police personnel in conflicts around the world. It is an effective way to systematically harm individuals and entire communities without putting the aggressor in an overtly dangerous situation. Women and girls in the DRC play a very submissive role in society and typically conform to traditional gender roles of male dominance and subsequent female subordination. Women and girls are valued for their reproductive capabilities and their sexual purity. Females in the DRC are direct victims of gender inequalities at all levels, leading to significant gaps in social, economic, and cultural capabilities.

In her article, Explaining Sexual Violence and Gender Inequalities in the DRC, Jane Freedman (2011) asserted that women are mainly concentrated in the informal and agricultural sectors of the economy, which leads to exploitation and a negation of economic decision making capabilities. ${ }^{5}$ Freedman also postulates there are significant gender inequalities in relation to the poverty line with $61.15 \%$ of female headed households living below the poverty line, compared to $54.32 \%$ of male-headed households. ${ }^{6}$ Furthermore, Freedman argues there are also large gender discrepancies in the DRC in terms of access to medical treatment, education, and due process in the criminal justice system. ${ }^{7}$ Such gender disparities further the patriarchal tendencies of the region and promote the suppression of women and girls. These traditional gender roles encourage females to be subordinate fixtures in a male dominated society and hinder the progression of gender equality and the liberation of women and girls from such bigotry.

4 "Gender, Equity and Human Rights," World Health Organization, accessed May 12, 2018, http://www. who.int/gender-equity-rights/understanding/gender-definition/en/

5 Jane Freedman, "Explaining Sexual Violence and Gender Inequalities in the DRC," Peace Review, 23:2, (2011):170-175.

6 Freedman, "Explaining Sexual Violence," 172.

7 Freedman, "Explaining Sexual Violence," 173. 
In a report published by the United Nations, the DRC was labelled the worst place in the world to be a woman and with good justification. ${ }^{8}$ In their article, Rape with Extreme Violence: The New Pathology in Eastern DR Congo, Denis Mukwege and Cathy Nangini (2009) assert on average 1,100 reported rapes occur each month in the DRC. ${ }^{9}$ These sexual attacks forced researchers to create a new category of rape due to their sadistic qualities: rape with extreme violence. Mukwege states the effectiveness of rape relies on, "the perception, deeply embedded in patriarchal societies, that women's sexuality is a prefecture of male ownership, and is linked to the persistence of unequal gender relations and particularly to the way women's bodies are regarded". ${ }^{10}$ The patriarchal inclinations of the region and the presence of intense conflict has led to the utilization of four different types of rape by aggressors. The first type of rape is gang rape, which is usually carried out by three or more men. This type of rape leads to more incidences of injury as it is quite violent. ${ }^{11}$ The second type of rape is genital mutilation, in which the perpetrators will rape their victim and then mutilate her genitals with guns, glass, or heated metals. One report stated that a young girl was gang raped publicly in the region, and after the initial attack the aggressors poured acid into her vagina while she remained bound. ${ }^{12}$ The third type of rape documented occurs when rape is utilized as a biological weapon through the intentional transference of sexually transmitted diseases. ${ }^{13}$ Many customary beliefs in the DRC assert girls who are still virgins are less likely to be HIV positive, or in certain circumstances can cure a man infected with HIV. ${ }^{14}$ Thus younger females have an increased risk of being raped by males infected with HIV. According to data released by UNAIDS, as of 2016 there are 48,000 children aged 0-14 living with HIV in the DRC. Moreover, an estimated 210,000 women aged 15 and over are living with HIV. When comparing this to the number of males aged 15 and over, 110,000, the propagation of rape becomes quite evident. ${ }^{15}$ These statistics illustrate the grave reality of the intentional transference of HIV/AIDS and the significant impact such transmissions have on children living in the DRC. The fourth documented type of rape happens when victims are forced

Yolanda Sadie. "Sexual and Gender-Based Violence in the Democratic Republic of Congo." African Security Review24 (4) (2015): 450-57.

9 Denis Mukwege and Cathy Nangini. "Rape with Extreme Violence: The New Pathology in Eastern DR Congo." PLoS Medicine (6): (2009): 1-5.

10 Mukwege, "Rape with Extreme Violence," 2.

11 Mukwege, "Rape with Extreme Violence," 2.

12 Shelly Whitman. "Sexual Violence, Coltan and the Democratic Republic of Congo." In Natural Resources and Social Conflict: Towards Critical Environmental Security, edited by Matthew A. Schnurr and Larry A. Swatuk, (2012): 128-51.

13 Mukwege, "Rape with Extreme Violence," 2.

14 Whitman, "Sexual Violence,"140.

15 "Democratic Republic of the Congo," UNAIDS, last modified May 22, 2018, http://www.unaids.org/ en/regionscountries/countries/democraticrepublicofthecongo. 
to rape each other. ${ }^{16}$ In her article, Rape and Sexual Violence in the Democratic Republic of Congo, Banwell (2012) asserts approximately $70 \%$ of documented rapes were premeditated with a specific focus to "terrorize, loot, rape and then leave". ${ }^{17}$

Furthermore, in an article published by Nelson et al. (2011) girls living in rural areas reported a "relatively higher proportion of gang rape (35.5\%), sexual slavery (35.4\%), or combined gang rape and sexual slavery, (47.4\%), and a lower proportion of rape [committed by a single assailant]" when compared to their urban counterparts. ${ }^{18}$ Additionally, Bartels et al. (2012) reported more than $60 \%$ of all sexual attacks reported in their region of study were incidences of gang rape with the use of extreme violence committed by militia and government military officials. ${ }^{19}$ Mukwege and Nangini found $57.3 \%$ of females interviewed believed that the extreme violence executed during their rape was proof that armed forces were intentionally attempting to exterminate Congolese people and communities to which these women belonged. ${ }^{20}$ Furthermore, $72 \%$ of rape victims reported that they were tortured during the rape itself, which included having foreign objects inserted into their vagina including sticks, pestles coated in chili pepper, and rifle barrels. These victims asserted these rapes were aimed at destroying the women's identity by means of ethnic cleansing and the intentional transmission of HIV/AIDS was an attempt to destroy entire communities, and the generations to come. ${ }^{21}$

In the DRC these three strategies; rape, sexualized violence, and gender discrimination; are repeatedly used by rebel and local government forces to purposefully harm children, specifically girls, in the region. According to a report released by Save the Children, it is estimated that approximately $30-40 \%$ of all children in armed groups were girls and virtually all girl soldiers have endured at least one type of the aforementioned rapes. ${ }^{22}$ It is worth noting this statistic does not include the female victims not directly involved in armed conflict. It is estimated nearly half of all the victims of sexual gender-based violence are girls less than 18 years of age. ${ }^{23}$ Young girls are typical targets of rebel and government forces for violent

16 Stacy Banwell. "Rape and Sexual Violence in the Democratic Republic of Congo: A Case Study of Gender-Based Violence," Journal of Gender Studies (2012): 45-58.

17 Banwell, "Rape and Sexual Violence," 49.

18 Brett Nelson et al. "Impact of Sexual Violence on Children in the Eastern Democratic Republic of Congo," Medicine, Conflict and Survival, (2011): 211-25.

19 Susan Bartels et al. "Militarized Sexual Violence in South Kivu, Democratic Republic of Congo," Journal of Interpersonal Violence, (2012): 340-58.

20 Mukwege, "Rape with Extreme Violence," 2.

21 Mukwege, "Rape with Extreme Violence," 2.

22 "Reaching the Girls. Study on Girls Associated with Armed Forces and Groups in the Democratic Republic of Congo." Save the Children, accessed April 10, 2018, https://resourcecentre. savethechildren.net/library/reaching-girls-study-girls-associated-armed-forces-and-groups-democratic-republic-congo. 
rape since they are easily captured and culturally trained to submit to dominant male figures. Therefore, the historical trend of rape in war coupled with prevalent patriarchal tendencies has led to a proliferation of widespread rape and male dominated violence directed at girls in the DRC.

\section{In the DRC these three strategies; rape, sexualized violence, and gender discrimination; are repeatedly used by rebel and local government forces to purposefully harm children, specifically girls, in the region.}

\section{SOCIAL AND PSYCHOSOCIAL}

The utilization of rape against girls in the DRC has significant social and psychosocial impacts for girls afflicted by such egregious attacks, and for communities. The dominance of patriarchal beliefs and attitudes in the DRC coupled with intense stigmatization of such violence has serious psychosocial repercussions for victims and alters the way in which she is able to operate within her community. Victims of rape tend to be rejected by their families and ostracized from their communities due to the patriarchal tendencies in the region and the valuation of a girl's virginity. ${ }^{24}$ In his book, They Fight Like Soldiers, They Die Like Children, Romeo Dallaire (2010) asserts the level of stigma raped girls face is immense. Dallaire observed that because of the fear of being stigmatized, many girls attempt to self-demobilize and try to hide the fact they were raped. However, this rarely works as they find it difficult to reconnect to their pre-recruitment past. ${ }^{25}$ This attempt to hide their attack leaves these girls unable to receive any emotional support and limits access to medical care to address their vaginal lesions, sexually transmitted infections (STIs), or any other treatment they require. Additionally, the difficultly girls have with reintegration due to the emotional and physical traumas they endured forces many to move from the community in which they were raised and live in solitude. This type of segregation and lack of protection puts these girls at a greater risk of reoccurring episodes of sexual attacks by militia forces. These ostracized girls typically become involved in the sex trade or become addicted to substances to cope with the trauma of their attack. ${ }^{26}$

24 Jennifer Scott et al. "A Qualitative Analysis of Psychosocial Outcomes among Women with Sexual Violence-Related Pregnancies in Eastern Democratic Republic of Congo." International Journal of Mental Health Systems (2017): 2-10.

25 Romeo Dallaire and Jessica Dee. Humphreys, They Fight Like Soldiers, They Die Like Children the Global Quest to Eradicate the Use of Child Soldiers. (Toronto: Random House, 2010), 176.

26 Graça Machel, "International Conference on War-Affected Children," The Impact of Armed Conflict on Children: a Critical Review of Progress Made and Obstacles Encountered in Increasing Protection for War-Affected Children, (2001):1-49. 
In a study published by Fuadd Freh (2016), he asserts that the presence of war has severely affected generations of children and youth, physically and psychologically for the rest of their lives. An important aspect of childhood is being raised in a safe and protective environment; however, girls victimized by gendered and sexualized violence are unable to experience such a familial dynamic. According to Freh, it is estimated that one third of children living in a war zone are vulnerable to developing some form of post-traumatic stress disorder (PTSD), psychopathological symptoms, and lower psychosocial function during their life time, which points to the volatile and violent environment in which they are living. ${ }^{27}$ The psychological consequences of experiencing conflict and the traumas associated with sexual violation therefore greatly impacts the social capabilities and psychosocial capacities of girls.

Moreover, the deeply rooted social constructs surrounding rape and the preconceived notions about gendered roles in society has an enormous impact on the ability of girls to reintegrate into society after a sexual attack. Stacy Banwell asserts women are disproportionately disadvantaged economically and socially in the DRC due to strong beliefs that women are of a lower status than men, which places them at a higher risk to be exposed to gender discrimination and sexual victimization during an armed conflict. ${ }^{28}$ In particular, it is increasingly challenging for girls who became pregnant or gave birth as a result of their attack to reintegrate into their community. Scott et al (2017) stated girls and women impregnated as a result of their rape face significant emotional distresses as a result of being rejected from their community. These individuals also anticipated they would lose social stability and a decline in future social opportunities due to their attack. ${ }^{29}$ Additionally, Dallaire asserts girls who became pregnant as a result of their attack are unable to attend school or receive training. The presence of an infant draws attention to their rape and further stigmatizes the victim. ${ }^{30}$ Girls who were sexually attacked and face unwanted pregnancy and children do not find adequate means in which to rebuild their lives within the normal construct of the social structure. ${ }^{31}$ Additionally, there is a lot of shame associated with the pregnancy and a great deal of fear. According to Trenholm et al. (2013) communities are not receptive to girls returning to their village, especially with children of rebel forces, because they fear retaliation by the armed forces that took her. ${ }^{32}$ These social constructs and the psychological implications of these stigmas makes it difficult for girls victimized by sexual violence to reintegrate into society or access services to assist in their

27 Fuaad Mohammed Freh, "Psychological Effects of War and Violence on Children," Journal of Psychological Abnormalities, (2016):1-2.

28 Banwell, "Rape and Sexual Violence," 51-52.

29 Jennifer Scott et al. "A Qualitative Analysis of Psychosocial Outcomes," 5.

30 Dallaire, They Fight Like Soldiers, 176.

31 Dallaire, They Fight Like Soldiers, 176.

32 Jill Trenholm, "Constructing Soldiers from Boys in Eastern Democratic Republic of Congo," Men and Masculinities, (2013):203-27. 
physical and emotional recovery. Therefore, ostracizing rape victims increases the impacts of sexual violence and creates a violent environment for young children.

Furthermore, girls taken as child soldiers face serious obstacles during their reintegration attempts because their societal value was negated during their attack. According to Romeo Dallaire, "young girls in such conflict zones become victims of two dehumanizing tragedies: being forced into the life of a child soldier and horrific sexual violence such as rape." ${ }^{33}$ Dallaire asserts that although boys face similar psychological and physical challenges it is easier for males to assimilate back into society because they can acquire new skills through education and training. However, for girls it is harder because she is viewed as having lost her purpose at the heart of the community. She no longer has the same marriage value and her children are considered non-persons. An ex-girl soldier knows if and when she returns to her village she will be seen as a disgrace to her family and her community even if she wasn't to blame for what happened to her. ${ }^{34}$

In addition, the social-cultural conceptions surrounding the rights of girls form significant barriers to their release from armed forces and reintegration efforts. Many cultural conceptions assert that a girl must remain with her first sexual partner, even if that partnership was the result of rape. According to a report released by Save the Children, military officials view young girls as a possession and not as children, thus asserting the captured girls are their 'wives' and not 'child soldiers' the latter of which they are obligated to demobilize. ${ }^{35}$ Additionally, there is a strong belief among communities that females must be submissive to their partner, which makes demobilizing these young girl soldiers an issue and creates a problem for rape victims since many girls are forced to stay with their rapist. ${ }^{36}$ Devaluation and dehumanization lead girls to remain with their rapists or rebel captors for security and survival. Roméo Dallaire argues the repeated acts of brutalized rape serves the sexual desires of those controlling the girls but he notes the most "insidious purpose is to undermine and alienate the child, making her a creature of the armed group. This form of torture also stigmatizes girls, especially within their cultural milieu, and makes it exceedingly hard for them to ever go home again." ${ }^{37}$ Therefore, patriarchal conceptions about the role of girls and women within male dominated societies tend to exacerbate violent situation and leads to more severe consequences for afflicted children.

33 Dallaire, They Fight Like Soldiers, 176.

34 Dallaire, They Fight Like Soldiers, 176-77.

35 Save the Children, "Reaching the Girls."

36 Brett Nelson "Impact of Sexual Violence," 220.

37 Dallaire, They Fight Like Soldiers, 134. 
The societal impact of sexualized violence and the consequences for children involved in conflict are far reaching and stem from deeply rooted political motivations and patriarchal suppression tactics. According to Sara Meger (2011) rebel forces utilize sexualized and gendered violence for societal gains. This has negative social impacts on afflicted individuals, especially young girls. Rebel forces use rape and sexual violence to divide communities and implant fear within individuals. ${ }^{38}$ Through the employment of sexual violence against girls, rebels effectively fragment the societal functioning of communities. Ruth Seifert asserts the women are what hold communities and family structures together, "their physical and emotional destruction aims at destroying social and cultural stability. In many cultures the female body embodies the nation as a whole. The rape of women of a community, culture, or nation can be regarded as a symbolic rape of the body of that community." ${ }^{39}$ Not only does sexual violence demoralize victims, it also leads to a demoralization of the community from which she originated. Meger asserts, "Sexual violence [is] effective in demoralizing and undermining the solidarity of the victimized community and is therefore an effective weapon of dispersal used by armed groups to gain control over an area containing a valuable resource and exploit the resource privilege." 40

Additionally, due to the severity of rape with extreme violence and the long-term individualistic repercussions, there is a higher degree of destructive consequences for the social cohesion of communities. When rape occurs in public the victim's identity is damaged more because of the abundant shame and public humiliation associated with rape. Not only is sexual violence devastating to the individual, it also affects the community as a whole, because the long-term repercussions of rape are translated into a slow decline in the population due to the victim's inability or unwillingness to conceive children. ${ }^{41}$

Furthermore, Mukwege asserts that on a micro community-based level, rape with extreme violence greatly damages "social cohesion and the identity of the rape survivor, which is exacerbated when rape is committed in public, searing shame into the collective memory of the community. The long-term outcomes translate into the slow death of a population incapable of reproducing. ${ }^{42}$ Moreover, on a macro community level Mukwege argues "the impact of military rape on the population as a whole has far-reaching effects that ultimately undermine national, political, and cultural solidarity; it confuses the loyalties of all survivors and the

38 Sara Meger, "Rape in Contemporary Warfare: The Role of Globalization in Wartime Sexual Violence," African Conflict and Peacebuilding Review (2011):100-132.

39 Seifert, R., "The Second Front: The Logic of Sexual Violence in Wars," Women's Studies International Forum, (1996): 35.

40 Meger, "Rape in Contemporary Warfare," 113.

41 Mukwege, "Rape with Extreme Violence," 2.

42 Mukwege, "Rape with Extreme Violence" 2. 
identities of subsequent generations." ${ }^{43}$ Finally, Banwell postulates because women are a vital component to the core of communities when adolescent girls are raped it is regarded as an attack on the entire community. ${ }^{44}$ Therefore, patriarchal tendencies and cultural conceptions surrounding traditional gender roles play a pivotal role in societal reintegration attempts and the significant level of stigma associated with rape creates an unforgiving and volatile community for children to be raised.

\section{ECONOMIC}

Children in conflict zones face numerous economic consequences which impact their productivity in society. The proliferation of rape and sexualized violence in the DRC also significantly influences the economic capabilities of its victims and the communities in which they reside. Many girls are unable to receive a formal education, which decreases their economic capabilities. This denial of education is caused by their experiences with sexualized violence and unequal gender relations within the region. Finally, due to the psychological, psychosocial, and physical impairments that occurred because of their attack, girls have a decreased productivity level making them uncompetitive candidates in the economy.

It is necessary to begin this section by addressing the role economic gain plays in the DRC's current conflict and the connection between economic objectives and sexual violence. The abundance of natural resources has played a pivotal role in the recurrent conflict and is partially to blame for the high prevalence of sexual violence. Séverine Autesserre in her book, The Trouble with the Congo: Local Violence and the Failure of International Peacebuilding, asserted the illegal exploitation of minerals and other natural resources in the Congo is a central motivation for the prevalence of violence committed by regional and national actors. ${ }^{45}$ Autesserre highlights that the involvement of regional and national actors produced violence in three ways: first both actors competed for control of mining regions; second, illegal exploitation of resources allowed armed groups to fund their combat efforts; third, all groups involved used extreme forms of violence against civilians, which included murder, rape, and torture, to gain control over the area or the ability to exploit the area. ${ }^{46}$

The instability created by conflict over resources and the lack of a legitimate government allowed rebels to further exploit the resources and gain control over important mining areas. Thus, this level of violence has become "an intrinsic part of the political economy of resource exploitation because it provides competing groups with a cover and power necessary to extract

\footnotetext{
43 Mukwege, "Rape with Extreme Violence," 2.

44 Banwell, "Rape and Sexual Violence," 52.

45 Séverine Autesserre, The Trouble with the Congo: Local Violence and the Failure of International Peacebuilding. (Cambridge: Cambridge University Press 2012), 65. 
the valuable commodities." ${ }^{47}$ Moreover, Meger asserts sexual violence is utilized by rebels and government officials because it "reinforces norms of hegemonic masculinity and exploits core social themes of honour, shame, family, and identity, has proven an effective method of maintaining a generalized state of violence and terror under the cloak of which armed groups are free to pursue their economic agendas." ${ }^{48}$ Therefore, the economic roots of this conflict, which has subsequently promoted sexualized violence in the region, has led to severe economic impacts, such as lack of education, lack of employment, and decreased economic capacity for those afflicted and has led to a further perpetuation of patriarchal tendencies and a promotion of sexualized violence directed at women and children.

\section{The instability created by conflict over resources and the lack of a legitimate government allowed rebels to further exploit the resources and gain control over important mining areas.}

Children raised in conflict zones are less likely to receive an education due to increased levels of violence and instability within the region. Due to prominent gender discrimination girls are less likely to receive any formal education compared to boys of the same age in the same region. One reason for this gender imbalance is the active recruitment of child soldiers and child brides from school zones. In a report published by the United Nations Educational, Scientific, and Cultural Office (UNESCO), it was asserted rebel groups systematically target schools and abduct children on their way to school to serve as child soldiers. This methodical recruitment of children likely decreases the incentive of many individuals to receive an education and also implants apprehension about placing children into the school system in fear they will be abducted. ${ }^{49}$ Furthermore, schools are reportedly ransacked by police and rebels and are occupied by both sides, which not only displaces the children who were supposed to be there but damages the school itself. ${ }^{50}$

It was estimated in 2010 15\% of girls aged 15 years had no formal education, compared to $10 \%$ of boys of the same age. Moreover, in 2010 girls between 13-17 years of age who lived in a war-affected area only received on average 2 years of education, compared to the 3 years of education received by boys in the same age group and region. ${ }^{51}$ Additionally, the female literacy rate, when compared to boys, was also quite devastating. In 2008 , only $40 \%$ of girls

\footnotetext{
47 Meger, "Rape in Contemporary Warfare," 113.

48 Meger, "Rape in Contemporary Warfare," 113.

49 "The Hidden Crisis: Armed Conflict and Education" United Nations Scientific and Cultural Organization, accessed May 12, 2018, http://unesdoc.unesco.org/images/0019/001907/190743e. $p d f \& p=D e v E x, 5069.1$.

50 UNESCO, "The Hidden Crisis."

51 UNESCO, "The Hidden Crisis."
} 
aged 15 years were literate, compared to $70 \%$ for boys in the same age group and region. ${ }^{52}$ This data signals a sharp gender inequality in education and also demonstrates how conflict impacts the economic capabilities of girls because this lack of educational attainment adds to the poverty levels experienced in the region and perpetuates the present conflict. Many girls do not attend school because they fear being abducted and raped and others do not receive an education because of patriarchal conceptions about gender roles. Additionally, those who escaped their captors are shunned from their communities and thus are unable to return to school. It was reported girls are faced with additional challenges to education such as early marriage, household chores, rape, poverty, and the prioritization of male education over female. Moreover, according to a report for UNIFOR's Social Justice Fund, nearly half of all women in the Eastern part of the DRC are illiterate and only $28 \%$ of girls are enrolled in

secondary school, which is a sharp difference compared to the $51 \%$ of boys. ${ }^{53}$ Therefore, it is evident that girls victimized by sexual violence and experience incidents of extreme rape are less likely to receive an education because of stigmas associated with their rape and fears of abduction while attending school leaving them with a decreased economic capability.

Furthermore, direct involvement in conflict has significant economic impacts on children. In her book, The War Crime of Child Soldier Recruitment, Julie McBride (2014) asserts children who had their perspectives and moral values changed by their experiences during conflict are more likely to have a difficult time readjusting to life after conflict subsides, they are generally not in a position to make an economic contribution to their community and turn to drug abuse and criminal activity, and in the case of young girls, prostitution. ${ }^{54}$ The economic impact of such conflict has direct implications for children and communities in which they reside and are made more severe when sexualized violence occurs. According to an article published by Rebecca Loya (2014), Rape as an Economic Crime, sexual violence impacts a victim's economic well-being in a number of ways, which reduces an individuals' earning power and impacts their economic wellbeing for months or years after the assault. Loya also found these economic consequences and loss of employment opportunities ultimately shift the victim's long-term economic trajectories. ${ }^{55}$ Loya argued the presence of sexual assault creates high economic expenditures for the individual and society as a whole. ${ }^{56}$ Due to the stigmatization of rape

52 UNESCO, "The Hidden Crisis."

53 "Democratic Republic of Congo: Redefining Gender Roles for women, building opportunities" UNIFOR Social Justice Fund, accessed April 10, 2018, https://www.unifor.org/sites/default/files/ attachments/sjf-casestudy-congowomen-en-v1.0.pdf

54 Julie McBride, The War Crime of Child Soldier Recruitment. (The Hague, The Netherlands: Asser Press, 2014).

55 Rebecca M Loya, "Rape as an Economic Crime." Journal of Interpersonal Violence (2014): 2793-2813. 
and sexual violence this economic impact has not been accurately measured in the DRC. The prevalence of mental health problems after an attack also negatively impacts a victim's economic well-being. Rape victims experience high levels of PSTD, depression, anxiety, and substance abuse, all of which negatively affect not only the economic well-being of the individual but puts a large strain on the economy of the community as a whole. ${ }^{57}$ Therefore, the presence of such high levels of gender and sexualized violence directed at girls damages the individualistic economic abilities and injures the economic capabilities of communities. Therefore, girls are impacted economically by sexual attacks because such incidents leave girls with lower educational attainment, decreased competitiveness in the economy, and an increased chance of reoccurring sexual assaults.

\section{PHYSICAL}

The physical impacts conflict has on children are horrendous. Children in the DRC are faced with deadly situations and girls especially are being raped, beaten, tortured, captured, murdered, and infected with HIV/AIDS and other sexually transmitted diseases. In her article, Girls in Fighting Forces: Moving Beyond Victimhood, Myriam Denov (2007) asserts "the violence and victimization experienced by girls ranged along a continuum from verbal abuse to outrageous acts of cruelty and reflected the patriarchal power relation and gendered oppression inherent in the armed group." ${ }^{158}$ These acts of cruelty are carried out as a systematic attack on an entire gender group. Girls are impacted significantly by conflict due to the use of sexualized violence directed at women. Denov argued girls attempt to negotiate with their commanders, using their bodies in exchange for hygiene products or food, or taking a husband to escape the more severe forms of abuse. ${ }^{59}$

Additionally, Dallaire asserted "rape is inevitable for the girls and sometimes for the boys. A resilient child soon learns that it is better to endear herself to one soldier with the gun and the power to protect her, than to be a communal sex object." ${ }^{\prime 60}$ Due to the powerful male dominant structure of armed forces girls become property of males, with their bodies being used as resources to be exploited and even as gifts or rewards. Girls in each of the contexts were thus constantly aware of the potential threat and danger of sexual violence by their adult commanders and other males within the armed groups. ${ }^{61}$

57 Loya, "Rape as an Economic Crime," 2796.

58 Denov, Myriam, "Girls in Fighting Forces: Moving Beyond Victimhood," Canadian International Development Agency, (2015): 1-36.

59 Denov. "Girls in Fighting Forces," 11.

60 Dallaire, They Fight Like Soldiers, 133.

61 Denov. "Girls in Fighting Forces," 14. 
This type of sexual exploitation leads to a proliferation of physical health problems among young girls. Denov postulates girls experience a multitude of gynecological problems as a result of rape, which include genital injury, infections, complications from forced and consensual abortions, complications due to childbirth, and sexually transmitted diseases. ${ }^{62}$ Dallaire further illustrates the physical impact such acts of extreme rape have on child victims. Dallaire asserts that many child sex slaves have contracted STIs and/or HIV/AIDS as a result of their repeated sexual attacks. He highlights that because of the unsanitary and dangerous conditions in which many girls are forced to give birth, many are even afflicted with fistula, which causes so much irreparable damage that many girls are unable to give birth again. ${ }^{63}$

Sexualized violence also occurs outside the confines of armed groups and is perpetuated in communities as well, whether by rebels, government officials, or community members. The presence of conflict makes it extremely difficult for girls to seek justice or access proper healthcare or counselling. In her article, Sexualized Violence, Coltan and the Democratic Republic of Congo, Shelly Whitman asserts that FARDC, the government army, is the single largest perpetrator of sexualized violence against girls. ${ }^{64}$ Moreover, Whitman argued that age is not a factor when it comes to victims of sexual violence, as $65 \%$ of sexual violence victims during 2008 were children, of which $10 \%$ were under the age of 10 . Additionally, between January 2010 and July 2010, 66 girls under the age of three were admitted to a single hospital for issues relating to sexual violence. ${ }^{65}$ Men target girls for a multitude of reasons, each of which has severe impacts on the physical health of females. Through the transmission of sexually transmitted diseases, the utilization of brutal torture techniques, and the long-lasting physical traumas associated with such heinous acts, the proliferation of rape against children has severely impacted their physical health.

\section{SUSTAINABLE DEVELOPMENT IN A CONFLICT ZONE}

In order to address the aforementioned issues of sexual and gendered violence, a sustainable development approach must be taken in the DRC. This approach should focus on the promotion of education, healthcare, security and good governance, and, most importantly, gender equality. Through simultaneous implementation of all four pillars there can be a growth in the legitimate economic capabilities of the region and an increase in the level of educational attainment which will also foster economic advancement.

Firstly, through the promotion of gender equality and educational programs which tackle the stigmas associated with rape, girls who were sexually attacked could access essential

\footnotetext{
62 Denov. "Girls in Fighting Forces," 20.

63 Dallaire, They Fight Like Soldiers, 177.

64 Whitman. "Sexual Violence," 139.

65 Whitman. "Sexual Violence, " 149.
} 
services more readily, reducing the impact sexual violence has on children and communities. Furthermore, with an increase in the accessibility of public education equally available to both boys and girls there can be an increase in the level of educational attainment and thus a decrease in unequal gender dynamics as they relate to education. It has been demonstrated that an individual in a developing country who has a completed primary education will receive, on average, a wage $143 \%$ higher than an individual with no education. ${ }^{66}$ Additionally, if an individual has successfully completed secondary education they will receive a wage that is $216 \%$ higher than an individual who has been denied an education. ${ }^{67}$ Without education, there is no hope for individuals to escape from poverty. In his book Common Wealth, Jeffery Sachs (2008) argued education enables individuals to acquire skills with which to navigate the economy, both locally and globally. ${ }^{68}$ Therefore, in order for education to be utilized by all, accessible programming needs to be implemented which aims to eliminate gender discrimination in the delivery of education to children.

\section{Therefore, in order for education to be utilized by all, accessible programming needs to be implemented which aims to eliminate gender discrimination in the delivery of education to children.}

Through healthcare promotion and medical training for local individuals, rape victims could be treated more easily and diseases associated with rape would not be as widespread throughout the region. Moreover, the ability to access medical treatment must also be addressed. There must be an increase in the availability of medical treatment for the general population of the DRC as well as specialized treatment for victims of sexualized violence. In his book Economic Growth, David Weil (2013) illustrates a parallel between health and income. He highlights the severe disparities between the 'developed' and the 'developing' in terms of access to healthcare. Weil argues, "among the rich countries of the Organization for Economic Co-operation and Development (OECD), there are an average of 2.2 doctors per thousand people; in the developing world, the average is .8; and in sub-Saharan Africa, the average is only .3." ${ }^{69}$ Therefore, a large emphasis needs to be placed on the promotion of healthcare in order to raise human capital, income per capita, and societal welfare. This access to healthcare must be equally available to both females and males to recognize gender equality through the provision of health services.

66 David Weil, Economic Growth, 3rd ed. (Boston: Addison-Wesley, 2013), 154.

67 Ibid.

68 Jeffrey Sachs, Common Wealth: Economics for a Crowded Planet (New York: Penguin, 2008).

69 Weil, Economic Growth, 154. 
Furthermore, the promotion of gender equality which weaves into each pillar must be addressed separately as well. Gender inequality can lead to decreased levels of welfare and income depending on how extreme the discrimination is. Naila Kabeer (2005) asserts gender inequality is often perpetuated by the presence of decreased welfare,

\begin{abstract}
Poverty and disempowerment generally go hand in hand because of an inability to meet one's basic needs - and the resulting dependence on powerful others to do so rules out the capacity for meaningful choice. This absence of choice is likely to affect women and men differently, because gender-related inequalities often intensify the effects of poverty. ${ }^{70}$
\end{abstract}

Additionally, Kabeer argued access to equal opportunity and access to resources also play a central role in poverty reduction. Without gender equality there is often an unequal distribution of resources, which exacerbates issues of poverty. Kabeer asserts that such unequal dispersal leaves males in a privileged position and gives them the ability to control the rules and conventions which are forced upon women. ${ }^{71}$ Therefore, through the promotion of gender equality there can be a decrease in the level of poverty prevalent because women can have equal access to resources and decision-making platforms. They can become empowered and have independent choice over their futures. Women can also acquire proper education, healthcare, and access to the labour market, all of which will benefit the entirety of society. There can be a decrease in infant mortality, maternal mortality, and a more sustainable level of population growth because women will be able to receive education on healthy reproductive patterns.

Finally, in order to provide citizens with adequate social services, the governmental faction must be able to organize itself in an efficient, non-corrupt manner, and be able to engage in healthy international relationships. In their book, Why Nations Fail, Daron Acemoglu and James Robinson (2012) argued many nations fail due to the political and economic institutions implemented in the state. Acemoglu and Robinson asserted that political institutions which utilize extractive measures tend to also have extractive economic institutions which lead to the enrichment of a few and the devaluation of many. They argued, "those who benefit from extractive institutions thus have the resources to build their (private) armies and mercenaries, to buy their judges, and to rig their elections in order to remain in power." ${ }^{72}$ Acemoglu and Robinson further assert the economic features of a state also largely contribute to the long run viability of the state. The extractive economic institutions often allow the practice of extractive

70 Nalia Kabeer, "Gender Equality and Women's Empowerment: A Critical Analysis of the Third Millennium Goal 1," Gender \& Development, (2005): 13-24.

71 Kabeer. "Gender Equality," 15.

72 Daron Acemoglu and James A. Robinson, Why Nations Fail: The Origins of Power, Prosperity, and Poverty, (New York: Crown, 2012) 343. 
political institutions to continue. The desire for unchecked power and civilian suppression allows such institutions to prevail and brings along with it the pillaging of national economic riches. $^{73}$ Therefore, in order to have a stable government able to provide beneficial social expenditures, there must be extensive checks on power, and a focus away from extractive political and economic decisions. Thus, with the implementation of legitimate government branches, not only can the perpetrators of egregious sexual attacks be tried, the rule of law can be established in the DRC. While such a plan will be difficult to implement in such a violent failed state, with the assistance of international organizations already present, along with the United Nations and international governing and security bodies, such a strategy can be implemented at a local level throughout the region.

\section{CONCLUSION}

In conclusion, gendered and sexualized violence are utilized as weapons of war in the Democratic Republic of Congo in a systematic attempt to destabilize the region. The use of violence has serious impacts on children, especially girls, in conflict zones and causes long term social and psychosocial, economic, and physical consequences for victims. This type of organized violence will prevail until the root issues of the conflict are addressed. Sustainable development needs to occur at a local level through the promotion of education, healthcare, good governance, security and policing, and, most importantly, gender equality. These pillars must be implemented into this failed state if there is any hope of sparing future generations from the turmoil and treachery of sexualized violence and mass systematic ethnic rape.

Airianna Murdoch-Fyke graduated Cum Laude from the University of Ottawa with a Joint Honours Bachelor of Social Science with specialization in Political Science and Economics and now attends law school at the University of Ottawa, where she is focusing much of her research on international law. Airianna is extremely passionate about the study of international politics and international economic structures. A key area of research interest for Airianna is the implementation of sustainable development in developing nations, which she hopes could successfully help communities achieve independence from oppressive systems and markets. 